The Free Internet Journal

for Organic Chemistry
Paper

Arkivoc 2020, part vii, 192-200

\title{
Synthesis of indolo[2,3-a]carbazole via an intramolecular McMurry coupling
}

\author{
Valerie Lösle and Hans-Joachim Knölker* \\ Fakultät Chemie, Technische Universität Dresden, Bergstraße 66, 01069 Dresden, Germany \\ Email: hans-joachim.knoelker@tu-dresden.de
}

Dedicated to Professor Jan Bergman on the occasion of his $80^{\text {th }}$ birthday

Received 08-05-2020

Accepted 08-26-2020

Published on line 09-04-2020

\section{Abstract}

The intramolecular McMurry coupling of a diprotected 3,3'-diformyl-2,2'-biindole as key step for the construction of the central six-membered ring provides a novel access to indolo[2,3-a]carbazole.<smiles>CC(C)(C)OC(=O)c1ccccc1-n1c(C=O)c2ccccc2c1-c1c(C=O)c2ccccc2n1C(=O)OC(C)(C)C</smiles>

Keywords: biindoles, Vilsmeier-Haack reaction, indolo[2,3-a]carbazole, McMurry coupling, titanium. 


\section{Introduction}

Indolo[2,3-a]carbazole (1) represents the parent framework for a wide range of alkaloids which have been isolated from various natural sources like cyanobacteria, slime moulds or marine invertebrates (Figure 1). ${ }^{1-5}$ The indolo[2,3-a]carbazole alkaloids display a wide range of useful pharmacological effects such as antifungal, antimicrobial, antihypertensive, and anticancer activities. ${ }^{1-8}$ Most of the naturally occurring indolo[2,3-a]carbazoles have an additional annulated pyrrole ring and belong to the subgroup of indolo[2,3-a]pyrrolo$[3,4-c]$ carbazole alkaloids. However, natural products lacking the additional pyrrole ring have also been isolated. The cytotoxic and antiviral 5-cyano-6-methoxy-11-methylindolo[2,3-a]carbazole (2) isolated by Moore and co-workers in 1990 from the blue-green alga Nostoc sphaericum EX-5-1 was the first representative. ${ }^{9}$ Shortly afterwards, on investigating Tolypothrix tjipanasensis the same group isolated the tjipanazoles which have been found as aglycones (e.g. $\mathbf{3 a}$ and $\mathbf{3 b}$ ) and as $N$-glycosides (e.g. $\mathbf{4 a}$ and $\mathbf{4 b}$ ). ${ }^{10}$

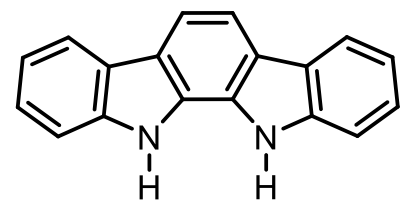

1 Indolo[2,3-a]carbazole<smiles>[R]c1ccc2[nH]c3c(ccc4c5cc(Cl)ccc5[nH]c43)c2c1</smiles>

3a Tjipanazol $\mathrm{D}(\mathrm{R}=\mathrm{Cl})$ 3b Tjipanazol I $(\mathrm{R}=\mathrm{H})$<smiles>COc1c(C#N)c2c3ccccc3[nH]c2c2c1c1ccccc1n2C</smiles>

2<smiles>[R]c1ccc2c(c1)c1ccc3c4cc(Cl)ccc4[nH]c3c1n2[C@@H]1OC[C@@H](O)[C@H](O)[C@H]1O</smiles>

4a Tjipanazol $B(R=C l)$

4b Tjipanazol F1 $(R=H)$

Figure 1. Indolo[2,3-a]carbazole (1) and naturally occurring derivatives 2-4.

Due to their broad range of useful biological activities, the indolo[2,3-a]carbazole alkaloids have been the focus of research since a long time and thus, numerous synthetic approaches to this framework have been developed. ${ }^{11,12}$ Besides the application of classical methods like the Fischer indolization, ${ }^{13,14}$ many approaches to indolo[2,3-a]carbazoles start from 2,2'-biindoles and involve a construction of the central carbocyclic ring, e.g. by palladium-catalyzed oxidative cyclization with alkynes, ${ }^{15}$ reductive cyclization with hydrazine, ${ }^{16}$ or ruthenium-catalyzed ring closing metathesis. ${ }^{17}$

Another useful alternative for the synthesis of cyclic alkenes is the intramolecular McMurry coupling which has been widely applied to the synthesis of natural products. ${ }^{18-22}$ The reductive coupling of carbonyl compounds induced by low-valent titanium, generally referred to as McMurry coupling, was originally discovered in the early 70 s. $^{23-25}$ It has emerged as an efficient and versatile tool for the preparation of complex olefinic structures. Herein, we describe a new approach to indolo[2,3-a]carbazole (1) using the intramolecular McMurry coupling of a 3,3'-diformyl-2,2'-biindole as key step. 


\section{Results and Discussion}

Retrosynthetic analysis of indolo[2,3- $a$ ]carbazole (1) based on construction of the central carbocyclic ring by an intramolecular McMurry coupling as the final step provides 2,2'-biindolyl-3,3'-dicarboxaldehyde (5) as precursor (Scheme 1). Bergman and co-workers have previously prepared compound 5 by a twofold Vilsmeier-Haack reaction of $2,2^{\prime}$-biindole $(6) .{ }^{26}$ For the synthesis of $\mathbf{6}$, we envisaged a palladium-catalyzed Suzuki-Miyaura coupling ${ }^{27,28}$ of the commercially available 2-indolylboronic acid $\mathbf{7}$ and 2-iodoindole (8).<smiles>c1ccc2c(c1)-c1ccc3c([nH]c4ccccc43)c1-2</smiles><smiles>c1ccc2[nH]c(-c3cc4ccccc4[nH]3)cc2c1</smiles>
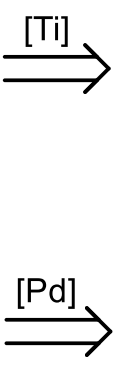

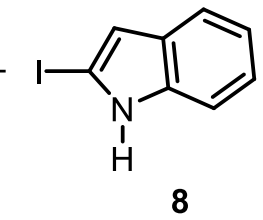

8

Scheme 1. Retrosynthetic analysis of indolo[2,3-a]carbazole (1) based on intramolecular McMurry coupling.

Bergman et al. have demonstrated that a twofold Madelung reaction provides a good access to 2,2'biindole (6). ${ }^{26}$ Alternatively, the central biaryl bond of $\mathbf{6}$ can be generated by a Suzuki-Miyaura coupling as previously reported by Young and coworkers. ${ }^{29}$ For the latter approach, we required 2-iodoindole (8) which was obtained in three steps from commercially available indole (9) (Scheme 2). Conversion of 9 into $\mathrm{N}$ phenylsulfonylindole (10) followed by lithiation at C-2 and subsequent metal-halogen exchange afforded 2iodo- $N$-phenylsulfonylindole (11) which on deprotection with tetrabutylammonium fluoride (TBAF) provided 2 -iodoindole (8) in three steps and 62\% overall yield from $\mathbf{9}$.

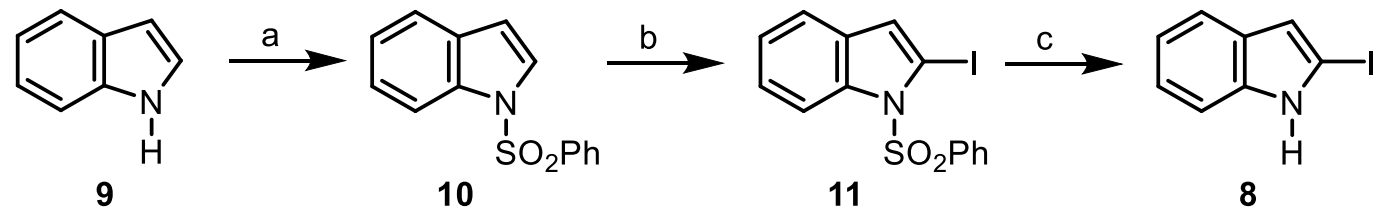

Scheme 2. Synthesis of 2-iodoindole (8). Reagents and conditions: (a) $\mathrm{PhSO}_{2} \mathrm{Cl}, \mathrm{NaH}, \mathrm{THF}, 0{ }^{\circ} \mathrm{C}$ to r.t., $19 \mathrm{~h}$, $95 \%$; (b) 1. LDA, THF, $-78{ }^{\circ} \mathrm{C}, 1.5 \mathrm{~h}$, then $0{ }^{\circ} \mathrm{C}, 1.5 \mathrm{~h}$; $2.1,2$-diiodoethane, $-78{ }^{\circ} \mathrm{C}$ to r.t., $17 \mathrm{~h}, 82 \%$; (c) TBAF, THF, reflux, $4 \mathrm{~h}, 80 \%$.

Suzuki-Miyaura coupling of 2-iodoindole (8) with N-Boc-2-indolylboronic acid (7) was achieved under microwave conditions as described by Young (Scheme 3). According to the literature, ${ }^{29}$ subsequent treatment with TFA was required to remove the protecting group. However, in our case deprotection occurred already during the chromatographic purification of the crude product, presumably due to the acidic nature of silica gel. Thus, 2,2'-biindole (6) could be obtained directly. A twofold Vilsmeier-Haack formylation of 6 using the 
conditions previously described by Bergman and coworkers ${ }^{26}$ afforded 2,2'-biindolyl-3,3'-dicarboxaldehyde (5) in excellent yield. In a first attempt to transform the 2,2'-biindole 5 into indolo[2,3-a]carbazole (1) by an intramolecular McMurry coupling reaction, a combination of titanium trichloride and zinc dust for generation of the low-valent titanium species was used. ${ }^{18,30}$ However, only small amounts of the desired coupling product 1 were obtained. Finally, using a combination of titanium tetrachloride with zinc-copper couple as reducing agent, ${ }^{18,23}$ we obtained indolo[2,3-a]carbazole (1) in $43 \%$ yield. We suspected that the moderate yield for the intramolecular coupling might be caused by complexation of titanium to the nitrogen atoms of the 2,2'biindole 5. Therefore, compound $\mathbf{5}$ was protected at both nitrogen atoms by Boc groups as described previously by de Koning et al. ${ }^{17}$ Intramolecular McMurry coupling of the resulting bis-Boc-protected 2,2'biindole 12 using the optimized reaction conditions provided directly indolo[2,3-a]carbazole (1) in 65\% yield. It is noteworthy that no Boc-protected indolo[2,3-a]carbazole was detected after aqueous work-up. Most likely the Boc groups are removed under the acidic conditions. The spectroscopic data of our indolo[2,3-a]carbazole (1) are in full agreement with those reported along with the previous syntheses of $\mathbf{1}^{13,14,16,31,32}$

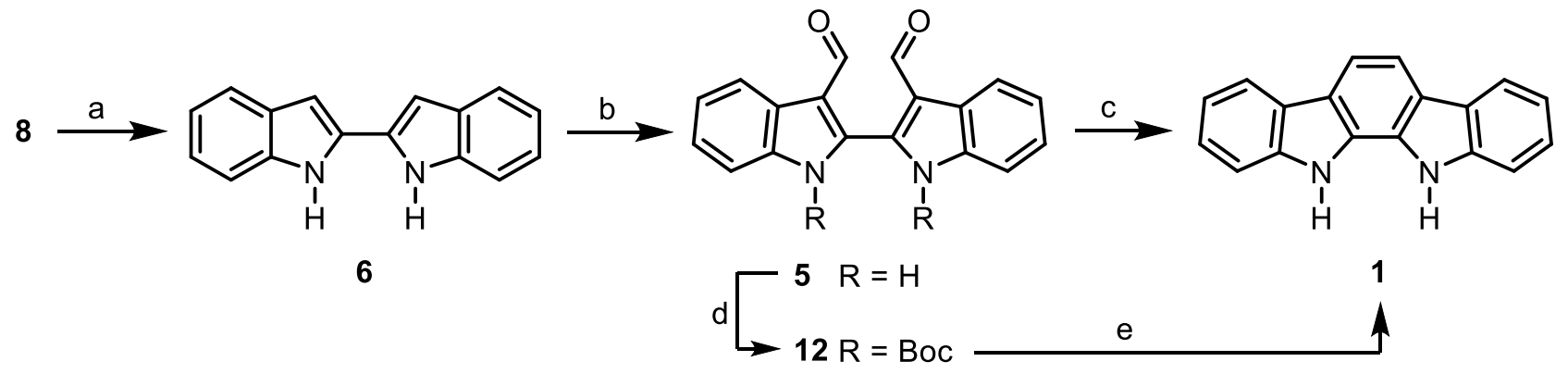

Scheme 3. Synthesis of indolo[2,3-a]carbazole (1). Reagents and conditions: (a) N-Boc-indole-2-boronic acid (7), $\mathrm{PdCl}_{2}\left(\mathrm{PPh}_{3}\right)_{2}, \mathrm{Na}_{2} \mathrm{CO}_{3}, \mathrm{MeCN} / \mathrm{H}_{2} \mathrm{O}$, microwave, $110{ }^{\circ} \mathrm{C}, 1.5 \mathrm{~h}, 100 \%$; (b) 1. $\mathrm{POCl}_{3}, \mathrm{DMF}, 0{ }^{\circ} \mathrm{C}$ to r.t., 2 d, 2.2 $\mathrm{M} \mathrm{NaOH}, 1 \mathrm{~h}$, reflux, 90\%; (c) $\mathrm{TiCl}_{4}, \mathrm{Zn} / \mathrm{Cu}$, THF, reflux, $26 \mathrm{~h}, 43 \%$; (d) $\mathrm{Boc}_{2} \mathrm{O}$, DMAP, THF, r.t., 30 min, 78\%; (e) $\mathrm{TiCl}_{4}, \mathrm{Zn} / \mathrm{Cu}$, THF, reflux, $20 \mathrm{~h}, 65 \%$.

\section{Conclusions}

We have developed a novel synthetic approach to indolo[2,3-a]carbazole (1) using the intramolecular McMurry coupling of a 3,3'-diformyl-2,2'-biindole as key step. The Suzuki-Miyaura cross coupling of 2iodoindole (8) and $\mathrm{N}$-Boc-2-indolylboronic acid (7) followed by a twofold Vilsmeier-Haack formylation affords $2,2^{\prime}$-biindolyl-3,3'-dicarboxaldehyde (5) in $90 \%$ yield over both steps. The intramolecular McMurry coupling of the unprotected compound $\mathbf{5}$ led to compound $\mathbf{1}$ in only moderate yield. We were able to show that the yield for the coupling reaction to 1 can be improved by twofold $N$-Boc protection of compound 5 . Thus, the McMurry coupling of compound 12 provided indolo[2,3-a]carbazole (1) in seven steps and $28 \%$ overall yield based on indole (9). Extension of the present route by using two differently substituted indole moieties for the Suzuki-Miyaura coupling step would lead to unsymmetrically substituted indolo[2,3-a]carbazole derivatives. 


\section{Experimental Section}

General. Starting reagents were purchased from commercial sources and used without additional purification. All reactions were carried out in oven-dried glassware under argon atmosphere using dry solvents, unless stated otherwise. Microwave irradiations were carried out using a CEM DISCOVER microwave apparatus with a maximum power of $300 \mathrm{~W}$ and a maximum pressure of 20 bar. Flash chromatography was performed using silica gel from Acros Organics $(0.035-0.070 \mathrm{~mm})$. TLC was performed with TLC plates from Merck (60 $\left.F_{254}\right)$ using UV light for visualization. Melting points were measured on a Gallenkamp MPD 350 melting point apparatus. Ultraviolet spectra were recorded on a PerkinElmer 25 UV/Vis spectrometer. Fluorescence spectra were obtained using a Varian Cary Eclipse spectrometer. IR Spectra were recorded on a Thermo Nicolet Avatar FT-IR spectrometer using the ATR method (attenuated total reflectance). NMR spectra were recorded on a Bruker Avance III 600 spectrometer. Chemical shifts $\delta$ are reported in ppm with the solvent signal as internal standard. Standard abbreviations were used to denote the multiplicities of the signals. El mass spectra were recorded by GC/MS-coupling using an Agilent Technologies 6890 N GC System equipped with a 5973 Mass Selective Detector (70 eV). ESI-HRMS were recorded on a Waters Xevo G2-XS QTOF mass spectrometer. Elemental analyses were measured on a EuroVector EuroEA3000 elemental analyzer.

1-(Phenylsulfonyl)-1H-indole (10). Sodium hydride (60\% dispersion in mineral oil, $1.36 \mathrm{~g}, 33.9 \mathrm{mmol})$ was added in portions to a stirred solution of $1 \mathrm{H}$-indole (9) $(3.00 \mathrm{~g}, 25.6 \mathrm{mmol})$ in THF $(48 \mathrm{~mL})$ at $0{ }^{\circ} \mathrm{C}$. After stirring for $1 \mathrm{~h}$ at the same temperature, phenylsulfonyl chloride $(5.46 \mathrm{~g}, 30.9 \mathrm{mmol})$ was added. The solution was then allowed to warm up to r.t. and stirring was continued overnight. After addition of a saturated aqueous solution of ammonium chloride, the organic layer was separated, and the aqueous layer was extracted with ethyl acetate. The combined organic layers were washed with brine and dried over magnesium sulfate. Evaporation of the solvent and column chromatography (isohexane/ethyl acetate, 18:1 to 9:1) of the residue on silica gel provided compound 10 as a beige solid $(6.21 \mathrm{~g}, 95 \%) ; \mathrm{mp} 77-78^{\circ} \mathrm{C}$ (lit. $\left.{ }^{33} 77.5-79{ }^{\circ} \mathrm{C}\right) .{ }^{1} \mathrm{H}$ NMR (600 MHz, DMSO-d $)_{\text {): } \delta} 6.85$ (dd, J 3.6, 0.9 Hz, 1H), 7.25 (td, J 7.2, 1.1 Hz, 1H), 7.34 (td, J 7.2, $1.1 \mathrm{~Hz}, 1 \mathrm{H}$ ), 7.57-7.61 $(\mathrm{m}, 3 \mathrm{H}), 7.67-7.70(\mathrm{~m}, 1 \mathrm{H}), 7.81(\mathrm{~d}, J 3.8 \mathrm{~Hz}, 1 \mathrm{H}), 7.94(\mathrm{~d}, J 8.3 \mathrm{~Hz}, 1 \mathrm{H}), 7.96-7.99(\mathrm{~m}, 2 \mathrm{H}) .{ }^{13} \mathrm{C}$ NMR and DEPT (151 MHz, DMSO-d $): \delta 109.6(\mathrm{CH}), 113.1(\mathrm{CH}), 121.7(\mathrm{CH}), 123.6(\mathrm{CH}), 124.8(\mathrm{CH}), 126.7(2 \mathrm{CH}), 127.0(\mathrm{CH})$, 129.9 (2 CH), 130.5 (C), 134.2 (C), 134.7 (CH), 137.1 (C). MS (EI): m/z (\%) 257 (91) [M] ${ }^{+}, 141$ (27), 116 (100), 89 (49), 77 (62), 63 (22), 51 (28). For further spectroscopic data, see refs. 33,34.

2-lodo-1-(phenylsulfonyl)-1H-indole (11). A solution of $2 \mathrm{M}$ lithium diisopropylamide in THF $(6.0 \mathrm{~mL}, 12 \mathrm{mmol})$ was diluted with THF $(15 \mathrm{~mL})$ and cooled to $-78^{\circ} \mathrm{C}$. Then, a solution of 10 (1.98 g, $\left.7.69 \mathrm{mmol}\right)$ in THF (20 mL) was added dropwise over a period of $10 \mathrm{~min}$. After stirring at $-78{ }^{\circ} \mathrm{C}$ for $1.5 \mathrm{~h}$, the solution was warmed to $0{ }^{\circ} \mathrm{C}$ and stirred for $1.5 \mathrm{~h}$, cooled to $-78{ }^{\circ} \mathrm{C}$, and then 1,2-diiodoethane $(3.36 \mathrm{~g}, 11.9 \mathrm{mmol})$ was added. After stirring at $-78{ }^{\circ} \mathrm{C}$ for $15 \mathrm{~min}$, the mixture was allowed to warm to r.t., and stirring was continued overnight. After addition of a saturated aqueous solution of ammonium chloride, the organic layer was separated, and the aqueous layer was extracted with dichloromethane. Subsequently, the combined organic layers were washed with water and brine, and dried over magnesium sulfate. After removal of the solvent, the crude product was purified by column chromatography (isohexane/ethyl acetate, 8:1) on silica gel to afford compound $\mathbf{1 1}$ as a brown solid (2.42 g, 82\%); mp 91-92 ${ }^{\circ} \mathrm{C}$ (lit. $\left.{ }^{35} 91-92{ }^{\circ} \mathrm{C}\right) .{ }^{1} \mathrm{H}$ NMR $\left(600 \mathrm{MHz}, \mathrm{DMSO}-d_{6}\right): \delta 7.22(\mathrm{~d}, J 0.8 \mathrm{~Hz}, 1 \mathrm{H})$, $7.24(\mathrm{td}, J$ J $7.5,0.8 \mathrm{~Hz}, 1 \mathrm{H}), 7.30(\mathrm{td}, J 8.5,1.3 \mathrm{~Hz}, 1 \mathrm{H}), 7.49(\mathrm{~d}, J 7.2 \mathrm{~Hz}, 1 \mathrm{H}), 7.58-7.62(\mathrm{~m}, 2 \mathrm{H}), 7.71(\mathrm{tt}, J 7.5$, $1.1 \mathrm{~Hz}, 1 \mathrm{H}), 7.84-7.87(\mathrm{~m}, 2 \mathrm{H}), 8.14(\mathrm{dd}, J 8.7,0.8 \mathrm{~Hz}, 1 \mathrm{H}) .{ }^{13} \mathrm{C}$ NMR and DEPT (151 MHz, DMSO- $\left.d_{6}\right): \delta 80.1(\mathrm{C})$, $114.8(\mathrm{CH}), 120.1(\mathrm{CH}), 123.9(\mathrm{CH}), 124.0(\mathrm{CH}), 125.0(\mathrm{CH}), 126.6(2 \mathrm{CH}), 129.9(2 \mathrm{CH}), 131.6(\mathrm{C}), 134.9(\mathrm{CH})$, 
137.3 (C), 137.7 (C). MS (EI): m/z (\%) 383 (87) [M] ${ }^{+}, 242$ (100), 141 (21), 115 (57), 114 (24), 77 (56), 51 (24). For further spectroscopic data, see ref. 35.

2-lodo-1H-indole (8). To a stirred solution of $11(2.24 \mathrm{~g}, 5.84 \mathrm{mmol})$ in THF (93 mL) a $1 \mathrm{M}$ solution of tetrabutylammonium fluoride in THF $(9.0 \mathrm{~mL}, 8.1 \mathrm{~g}, 9.0 \mathrm{mmol})$ was added at r.t., and the resulting reaction mixture was heated under reflux conditions for $4 \mathrm{~h}$. After cooling to r.t. and addition of water $(150 \mathrm{~mL})$, the organic layer was separated and the aqueous layer was extracted with ethyl acetate. The combined organic layers were washed with brine, and dried over magnesium sulfate. Evaporation of the solvent and column chromatography (isohexane/ethyl acetate, 20:1) of the residue on silica gel provided compound $\mathbf{8}$ as a pale pink solid (1.14 g, 80\%); mp 79-81 ${ }^{\circ} \mathrm{C}$ (lit. ${ }^{36} 79-81{ }^{\circ} \mathrm{C}$ ). UV (MeOH): 269, 282 (sh), $291 \mathrm{~nm}$. Fluorescence (MeOH, exc. $269 \mathrm{~nm}$ ): 310, 367, $383 \mathrm{~nm}$. IR (ATR): 3363, 3063, 3045, 2920, 2587, 1932, 1895, 1774, 1475, $1457,1431,1396,1361,1331,1310,1273,1223,1111,1092,985,931,909,887,784,738,606 \mathrm{~cm}^{-1} .{ }^{1} \mathrm{H}$ NMR $\left(600 \mathrm{MHz}, \mathrm{CDCl}_{3}\right): \delta 6.72(\mathrm{dd}, J 2.1,0.9 \mathrm{~Hz}, 1 \mathrm{H}), 7.08(\mathrm{td}, J 7.2,1.1 \mathrm{~Hz}, 1 \mathrm{H}), 7.13(\mathrm{td}, J 7.2,1.1 \mathrm{~Hz}, 1 \mathrm{H}), 7.33$ (dd, J 8.1, $0.9 \mathrm{~Hz}, 1 \mathrm{H}), 7.54(\mathrm{dd}, J 7.9,0.8 \mathrm{~Hz}, 1 \mathrm{H}), 8.08(\mathrm{br} \mathrm{s}, 1 \mathrm{H}) .{ }^{13} \mathrm{C} \mathrm{NMR}$ and DEPT (151 MHz, $\left.\mathrm{CDCl}_{3}\right): \delta 74.7$ (C), $110.1(\mathrm{CH}), 112.7(\mathrm{CH}), 119.2(\mathrm{CH}), 120.3(\mathrm{CH}), 122.3(\mathrm{CH}), 129.6$ (C), 138.7 (C). MS (EI): $\mathrm{m} / \mathrm{z}(\%) 243(100)[\mathrm{M}]^{+}$, 127 (19), 116 (33), 89 (51), 63 (17), 39 (8). Anal. calcd for $\mathrm{C}_{8} \mathrm{H}_{6} \mathrm{IN}$ : C, 39.53; H, 2.49; N, 5.76. Found: C, 39.79; H, $2.23 ; \mathrm{N}, 5.74 \%$.

$1 H, 1^{\prime} H-2,2^{\prime}$-Biindole (6). A sealed microwave tube was charged with $\mathrm{N}$-(tert-butoxycarbonyl)indole-2-boronic acid (7) (194 mg, $743 \mu \mathrm{mol})$, bis(triphenylphosphine)palladium(II) dichloride (41.2 mg, $58.7 \mu \mathrm{mol})$, and sodium carbonate $(128 \mathrm{mg}, 1.21 \mathrm{mmol})$ and the mixture was purged with argon several times. Then, a solution of 8 $(122 \mathrm{mg}, 500 \mu \mathrm{mol})$ in degassed acetonitrile $(1.6 \mathrm{~mL})$ and degassed water $(0.36 \mathrm{~mL})$ was added. The reaction mixture was heated in the sealed tube under argon atmosphere by microwave at $110^{\circ} \mathrm{C}$ for $1 \mathrm{~h}$. After cooling to r.t., the mixture was partitioned between ethyl acetate and water, the organic layer was separated, and the aqueous layer was extracted with ethyl acetate. The combined organic layers were washed with brine, and dried over magnesium sulfate. After removal of the solvent, the crude product was purified by column chromatography (isohexane/ethyl acetate, 9:1 to 3:1) on silica gel to give compound 6 as a red solid $(116 \mathrm{mg}$, 100\%). ${ }^{1} \mathrm{H}$ NMR ( $600 \mathrm{MHz}$, DMSO- $d_{6}$ ): $\delta 6.91$ (dd, J 2.3, $0.8 \mathrm{~Hz}, 2 \mathrm{H}$ ), 7.00 (td, J 7.2, $1.1 \mathrm{~Hz}, 2 \mathrm{H}$ ), 7.10 (td, J 7.2, $1.1 \mathrm{~Hz}, 2 \mathrm{H}), 7.39(\mathrm{dd}, J 8.3,0.8 \mathrm{~Hz}, 2 \mathrm{H}), 7.55(\mathrm{~d}, J 7.5 \mathrm{~Hz}, 2 \mathrm{H}), 11.53(\mathrm{~s}, 2 \mathrm{H}) .{ }^{13} \mathrm{C}$ NMR and DEPT (151 MHz, DMSO-d $\left.d_{6}\right): \delta 98.4(2 \mathrm{CH}), 111.1(2 \mathrm{CH}), 119.4(2 \mathrm{CH}), 120.0(2 \mathrm{CH}), 121.7(2 \mathrm{CH}), 128.5(2 \mathrm{C}), 131.4(2 \mathrm{C}), 136.9$ (2 C). MS (EI): m/z (\%) 233 (17), 232 (100) [M] ${ }^{+}, 231$ (50), 204 (15), 116 (12), 102 (7), 89 (7). For further spectroscopic data, see refs. 26,37 .

1H,1'H-2,2'-Biindole-3,3'-dicarboxaldehyde (5). Phosphorus oxychloride (804 mg, $5.37 \mathrm{mmol}$ ) was added slowly to DMF $(2.0 \mathrm{~mL})$ at $0{ }^{\circ} \mathrm{C}$, and the resulting mixture was allowed to stir at that temperature for $25 \mathrm{~min}$, before a solution of $6(479 \mathrm{mg}, 2.06 \mathrm{mmol})$ in DMF $(10 \mathrm{~mL})$ was added dropwise over a period of $1.5 \mathrm{~h}$. The mixture was allowed to warm up to r.t. and stirring was continued for further $43 \mathrm{~h}$. Then, $2 \mathrm{M}$ aqueous $\mathrm{NaOH}$ $(40 \mathrm{~mL})$ was added under cooling and the mixture was heated at reflux for $1 \mathrm{~h}$. After cooling to r.t., the resulting precipitate was isolated by filtration, washed with water and dried in vacuo to leave compound 5 as a yellow solid (538 mg, 90\%); mp 274-275 ${ }^{\circ} \mathrm{C} .{ }^{1} \mathrm{H}$ NMR (600 MHz, DMSO-d 6 ): $\delta 7.35$ (td, J 7.2, $1.1 \mathrm{~Hz}, 2 \mathrm{H}$ ), 7.41 (td, J 7.2, $1.1 \mathrm{~Hz}, 2 \mathrm{H}), 7.61(\mathrm{dt}, J$ J.9, $0.8 \mathrm{~Hz}, 2 \mathrm{H}), 8.29(\mathrm{~d}, J 7.5 \mathrm{~Hz}, 2 \mathrm{H}), 10.04(\mathrm{~s}, 2 \mathrm{H}), 12.94(\mathrm{~s}, 2 \mathrm{H}) .{ }^{13} \mathrm{C} \mathrm{NMR}$ and DEPT (151 MHz, DMSO- $\left.d_{6}\right): \delta 112.6(2 \mathrm{CH}), 116.5(2 \mathrm{C}), 121.3(2 \mathrm{CH}), 123.2(2 \mathrm{CH}), 124.9(2 \mathrm{CH}), 125.4(2 \mathrm{C})$, 136.3 (2 C), 136.7 (2 C), 185.6 (2 CHO). MS (EI): $m / z$ (\%) 289 (19), 288 (98) [M] $]^{+}, 260$ (22), 259 (100), 232 (34), 231 (35), 204 (25). For further spectroscopic data, see refs. 26,38.

Di-tert-Butyl 3,3'-diformyl-1H,1'H-[2,2'-biindole]-1,1'-dicarboxylate (12). Di-tert-butyl dicarbonate $(762 \mathrm{mg}$, $3.49 \mathrm{mmol}$ ) and 4-(dimethylamino)pyridine $(73.1 \mathrm{mg}, 560 \mu \mathrm{mol})$ were added to a suspension of $5(259 \mathrm{mg}, 898$ $\mu \mathrm{mol})$ in THF $(26 \mathrm{~mL})$ and the resulting mixture was stirred at r.t. for 30 min while forming a homogeneous 
solution. Removal of the solvent under reduced pressure and column chromatography (isohexane/ethyl acetate, 4:1) of the residue on silica gel afforded compound 12 as a yellow solid (343 mg, 78\%); mp 289-290 ${ }^{\circ} \mathrm{C} .{ }^{1} \mathrm{H}$ NMR $\left(600 \mathrm{MHz}, \mathrm{DMSO}-d_{6}\right): \delta 1.21(\mathrm{~s}, 18 \mathrm{H}), 7.48-7.52(\mathrm{~m}, 2 \mathrm{H}), 7.57-7.60(\mathrm{~m}, 2 \mathrm{H}), 8.28-8.33(\mathrm{~m}, 4 \mathrm{H})$, $9.80(\mathrm{~s}, 2 \mathrm{H}) .{ }^{13} \mathrm{C}$ NMR and DEPT (151 MHz, DMSO-d $\left.d_{6}\right): \delta 27.1\left(6 \mathrm{CH}_{3}\right), 85.7(2 \mathrm{C}), 115.5(2 \mathrm{CH}), 121.4(2 \mathrm{CH})$, 122.5 (2 C), 124.9 (2 C), 125.1 (2 CH), 127.1 (2 CH), 135.8 (2 C), 136.2 (2 C), 148.3 (2 C=0), 187.2 (2 CHO). MS (EI): m/z (\%) 289 (19), 288 (96), 260 (22), 259 (100), 232 (36), 231 (39), 204 (27) (note: due to the easy elimination of the Boc groups during vaporization, no $[\mathrm{M}]^{+}$-peak can be observed). For further spectroscopic data, see ref. 17.

$\mathbf{1 1 H , 1 2 H}$-Dihydroindolo[2,3-a]carbazole (1). (a) Direct synthesis from $\mathbf{5}$. Titanium tetrachloride $(1.3 \mathrm{~mL}, 2.3 \mathrm{~g}$, $15 \mathrm{mmol}$ ) was added dropwise under stirring to THF $(50 \mathrm{~mL})$ at $0{ }^{\circ} \mathrm{C}$. The resulting yellow solution was warmed up to r.t., and zinc-copper couple $(2.28 \mathrm{~g}, 28.0 \mathrm{mmol})$ was added in portions to form a brownish suspension. After stirring at r.t. for $15 \mathrm{~min}$, the mixture was heated under reflux for $1 \mathrm{~h}$, and subsequently a solution of compound 5 (101 mg, $350 \mu \mathrm{mol})$ in THF (60 mL) was added over a period of $18 \mathrm{~h}$. Heating under reflux was continued for further 9 h. After cooling to r.t., a $20 \%$ aqueous solution of potassium carbonate $(50 \mathrm{~mL}) \mathrm{was}$ added to the reaction mixture, and the mixture was stirred for $1 \mathrm{~h}$ at r.t. After transfer into a separating funnel and vigorous shaking, the dark blue suspension decolorized and a white solid was formed, which was removed by filtration. The organic layer was separated, washed with brine, and dried over magnesium sulfate. Evaporation of the solvent in vacuo and column chromatography (pentane/ethyl acetate, 3:1) of the residue on silica gel provided compound 1 as a green solid (38.9 mg, 43\%). For the spectroscopic data of 1 , see below.

(b) Synthesis by reduction of 12. Titanium tetrachloride $(2.7 \mathrm{~mL}, 4.7 \mathrm{~g}, 25 \mathrm{mmol})$ was added dropwise under stirring to THF $(50 \mathrm{~mL})$ at $0{ }^{\circ} \mathrm{C}$. The resulting yellow solution was warmed up to r.t., and zinc-copper couple (3.61 g, $44.4 \mathrm{mmol}$ ) was added in portions to form a brownish suspension. After stirring at r.t. for $15 \mathrm{~min}$, the mixture was heated under reflux for $1 \mathrm{~h}$, and subsequently a solution of compound 12 (201 mg, $411 \mu \mathrm{mol})$ in THF $(75 \mathrm{~mL}$ ) was added over a period of $14 \mathrm{~h}$. Heating under reflux was continued for further $7 \mathrm{~h}$. After cooling to r.t., a $20 \%$ aqueous solution of potassium carbonate $(60 \mathrm{~mL})$ was added to the reaction mixture, and the mixture was stirred for $1 \mathrm{~h}$ at r.t. After transfer into a separating funnel and vigorous shaking, the dark blue suspension decolorized and a white solid was formed, which was removed by filtration. The organic layer was separated, washed with brine, and dried over magnesium sulfate. Evaporation of the solvent in vacuo and column chromatography (pentane/ethyl acetate, 3:1) of the residue on silica gel provided compound 1 as a green solid (68.8 mg, 65\%); $\mathrm{mp}>300^{\circ} \mathrm{C}$. UV (MeOH): 241 (sh), 255, 284, 310 (sh), 323, 340, $355 \mathrm{~nm}$. Fluorescence (MeOH, exc. $323 \mathrm{~nm}$ ): 365, $382 \mathrm{~nm}$. IR (ATR): 3742, 3401, 3052, 2922, 2850, 2033, 1935, 1894, $1868,1641,1614,1567,1441,1325,1218,1151,1118,1011,929,854,806,735,652 \mathrm{~cm}^{-1} .{ }^{1} \mathrm{H} \mathrm{NMR}(600 \mathrm{MHz}$, DMSO- $d_{6}$ ): $\delta 7.20$ (ddd, J 7.7, 7.0, $\left.1.0 \mathrm{~Hz}, 2 \mathrm{H}\right), 7.38$ (ddd, J 8.1, 7.0, $1.1 \mathrm{~Hz}, 2 \mathrm{H}$ ), $7.68(\mathrm{dt}, J 8.1,0.8 \mathrm{~Hz}, 2 \mathrm{H}), 7.91$ $(\mathrm{s}, 2 \mathrm{H}), 8.15(\mathrm{~d}, J 7.8 \mathrm{~Hz}, 2 \mathrm{H}), 11.05(\mathrm{~s}, 2 \mathrm{H}) .{ }^{13} \mathrm{C}$ NMR and DEPT (151 MHz, DMSO-d 6$): \delta 111.6(4 \mathrm{CH}), 118.9(2$ $\mathrm{CH}), 119.7$ (2 CH), 120.1 (2 C), 123.8 (2 C), 124.5 (2 CH), 125.7 (2 C), 139.0 (2 C). MS (El): m/z (\%) 257 (20), 256 (100) [M] ${ }^{+}, 255$ (35), 253 (5), 227 (5), 128 (17), 114 (5). HRMS (ESI) calcd for $\mathrm{C}_{18} \mathrm{H}_{12} \mathrm{~N}_{2}{ }^{+}: \mathrm{m} / z$ 256.0995; found: $m / z 256.0991$.

\section{Supplementary Material}

${ }^{1} \mathrm{H}$ and ${ }^{13} \mathrm{C}$ NMR spectra of all compounds 


\section{References}

1. Bergman, J.; Janosik, T.; Wahlström, N. In Adv. Heterocycl. Chem.; Vol. 80; Katritzky, A. R., Ed.; Academic Press: New York, 2001; pp 1-71.

https://doi.org/10.1016/S0065-2725(01)80012-X

2. Gribble, G. W.; Berthel, S. J. In Studies in Natural Products Chemistry: Stereoselective Synthesis (Part H);

Rahman, A., Ed.; Elsevier: Amsterdam, 1993; pp 365-409.

https://doi.org/10.1016/B978-0-444-89366-6.70015-0

3. Knölker, H.-J.; Reddy, K. R. Chem. Rev. 2002, 102, 4303-4427.

https://doi.org/10.1021/cr020059j

4. Sánchez, C.; Méndez, C.; Salas, J. A. Nat. Prod. Rep. 2006, 23, 1007-1045.

https://doi.org/10.1039/b601930g

5. Knölker, H.-J.; Schmidt, A. W.; Reddy, K. R. Chem. Rev. 2012, 112, 3193-3328.

https://doi.org/10.1021/cr200447s

6. Prudhomme, M. Curr. Pharm. Des. 1997, 3, 265-290.

7. Pindur, U.; Kim, Y.-S.; Mehrabani, F. Curr. Med. Chem. 1999, 6, 29-69.

8. Nakano, H.; Omura, S. J. Antibiot. 2009, 62, 17-26.

https://doi.org/10.1038/ja.2008.4

9. Knübel, G.; Larsen, L. K.; Moore, R. E.; Levine, I. A.; Patterson, G. M. L. J. Antibiot. 1990, 43, $1236-1239$. https://doi.org/10.7164/antibiotics.43.1236

10. Bonjouklian, R.; Smitka, T. A.; Doolin, L. E.; Molloy, R. M.; Debono, M.; Shaffer, S. A.; Moore, R. E.; Stewart, J. B.; Patterson, G. M. L. Tetrahedron 1991, 47, 7739-7750.

https://doi.org/10.1016/S0040-4020(01)81932-3

11. Janosik, T.; Wahlström, N.; Bergman, J. Tetrahedron 2008, 64, 9159-9180.

https://doi.org/10.1016/j.tet.2008.06.101

12. Janosik, T.; Rannug, A.; Rannug, U.; Wahlström, N.; Slätt, J.; Bergman, J. Chem. Rev. 2018, 118, 9058-9128. https://doi.org/10.1021/acs.chemrev.8b00186

13. Hu, Y. Z.; Chen, Y. Q. Synlett 2005, 1, 42-48.

https://doi.org/10.1055/s-2004-835667

14. Kotha, S.; Saifuddin, M.; Aswar, V. R. Org. Biomol. Chem. 2016, 14, 9868-9873.

https://doi.org/10.1039/c6ob01679k

15. Shi, Z.; Ding, S.; Cui, Y.; Jiao, N. Angew. Chem. Int. Ed. 2009, 48, 7895-7898.

https://doi.org/10.1002/anie.200903975

16. Banerji, A.; Bandyopadhyay, D.; Basak, B.; Biswas, P. K.; Banerji, J.; Chatterjee, A. Chem. Lett. 2005, 34, 1500-1501.

https://doi.org/doi.org/10.1246/cl.2005.1500

17. Pelly, S. C.; Parkinson, C. J.; van Otterlo, W. A. L.; de Koning, C. B. J. Org. Chem. 2005, 70, 10474-10481. https://doi.org/10.1021/jo051826s

18. McMurry, J. E.; Fleming, M. P.; Kees, K. L.; Krepski, L. R. J. Org. Chem. 1978, 43, 3255-3266. https://doi.org/10.1021/jo00411a002

19. McMurry, J. E. Acc. Chem. Res. 1983, 16, 405-411.

https://doi.org/10.1021/ar00095a003

20. McMurry, J. E. Chem. Rev. 1989, 89, 1513-1524.

https://doi.org/10.1021/cr00097a007 
21. Fürstner, A.; Bogdanović, B. Angew. Chem. Int. Ed. Engl. 1996, 35, 2442-2469.

https://doi.org/10.1002/anie.199624421

22. Ephritikhine, M. Chem. Commun. 1998, 2549-2554.

https://doi.org/10.1039/a804394i

23. Mukaiyama, T.; Sato, T.; Hanna, J. Chem. Lett. 1973, 2, 1041-1044.

https://doi.org/doi.org/10.1246/cl.1973.1041

24. Tyrlik, S.; Wolochowicz, I. Bull. Soc. Chim. Fr. 1973, 2147.

25. McMurry, J. E.; Fleming, M. P. J. Am. Chem. Soc. 1974, 96, 4708-4709.

https://doi.org/10.1021/ja00821a076

26. Bergman, J.; Koch, E.; Pelcman, B. Tetrahedron 1995, 51, 5631-5642.

https://doi.org/10.1016/0040-4020(95)00223-U

27. Miyaura, N.; Suzuki, A. Chem. Rev. 1995, 95, 2457-2483.

https://doi.org/10.1021/cr00039a007

28. Suzuki, A.; Yamamoto, Y. Chem. Lett. 2011, 40, 894-901.

https://doi.org/10.1246/cl.2011.894

29. Kumar, N. S.; Dullaghan, E. M.; Finlay, B. B.; Gong, H.; Reiner, N. E.; Selvam, J. J. P.; Thorson, L. M.;

Campbell, S.; Vitko, N.; Richardson, A. R.; Zoraghi, R.; Young, R. N. Bioorg. Med. Chem. 2014, 22, 17081725.

https://doi.org/10.1016/j.bmc.2014.01.020

30. Hupperts, A.; Fürstner, A.; Ptock, A.; Janssen, E. J. Org. Chem 1994, 59, 5215-5229.

https://doi.org/10.1021/jo00097a024

31. Carter, D. S.; Van Vranken, D. L. J. Org. Chem. 1999, 64, 8537-8545.

https://doi.org/10.1021/jo9909249

32. Abe, T.; Ishikura, M. Heterocycles 2015, 90, 673-680.

https://doi.org/10.3987/COM-14-S(K)28

33. Ibaceta-Lizana, J. S. L.; Jackson, A. H.; Prasitpan, N.; Shannon, P. V. R. J. Chem. Soc., Perkin Trans. 2 1987, 1221-1226.

https://doi.org/10.1039/P29870001221

34. Yoshida, K.; Hayashi, K.; Yanagisawa, A. Org. Lett. 2011, 13, 4762-4765.

https://doi.org/10.1021/ol201510u

35. Naka, H.; Akagi, Y.; Yamada, K.; Imahori, T.; Kasahara, T.; Kondo, Y. Eur. J. Org. Chem. 2007, $4635-4637$. https://doi.org/10.1002/ejoc.200700525

36. Yudin, L. G.; Pavlyuchenko, A. I.; Kost, A. N. Zh. Obshch. Khim. 1969, 39, 2784.

37. García-Rubia, A.; Urones, B.; Arrayás, R. G.; Carretero, J. C. Chem. Eur. J. 2010, 16, 9676-9685.

https://doi.org/10.1002/chem.201001126

38. Banerji, A.; Bandyopadhyay, D.; Basak, B. Heterocycles 2004, 63, 2371-2377.

https://doi.org/10.3987/COM-04-10142 